\title{
Sequence Tagged Site Markers to Rsp1, Rsp2, and Rsp3 Genes for Resistance to Septoria Speckled Leaf Blotch in Barley
}

\author{
S. H. Lee and S. M. Neate
}

Department of Plant Pathology, North Dakota State University, Fargo 58105. Accepted for publication 18 August 2006.

\begin{abstract}
Lee, S. H., and Neate, S. M. 2007. Sequence tagged site markers to Rsp 1 , $R s p 2$, and $R s p 3$ genes for resistance to Septoria speckled leaf blotch in barley. Phytopathology 97:162-169.

Five random amplified polymorphic DNA markers, two in coupling (OPAH5 $545 \mathrm{C}$, and OPBA $12_{314 \mathrm{C}}$ ) and three in repulsion phase $\left(\mathrm{UBC} 285_{158 \mathrm{R}}, \mathrm{OPC} 2_{441 \mathrm{R}}\right.$, and $\left.\mathrm{OPB} 17_{451 \mathrm{R}}\right)$, closely linked to Rsp genes conferring resistance to Septoria speckled leaf blotch (SSLB), were identified using bulked segregant analysis in three $F_{2}$ populations, each containing a $R s p$ gene. These markers were converted into the sequence tagged site (STS) markers SUBC285, SOPC2, SOPAH5, and SOPBA12. Another STS marker (MWG938) linked to Rsp2 in coupling phase was also identified in an $F_{2}$ population from the cross Robust/CIho 4780 . The

STS markers were tested on a set of 42 resistant and susceptible barley germplasm lines and 98 landraces. The expected sizes of marker fragments associated with each allele at $R s p$ loci were present in resistant or susceptible accessions. Efficiency of marker-assisted selection (MAS) for $R s p 1, R s p 2$, and $R s p 3$ using STS markers were evaluated in three $\mathrm{F}_{2-3}$ populations in the greenhouse and the field. Results of testing $\mathrm{F}_{2-3}$ progeny demonstrated that the accuracy of MAS was, with one exception, greater than $97 \%$ in the greenhouse and in two field locations $(90 \%$ in the Osnabrock, ND trial for $R s p 2$ ). The STS markers closely linked to Rsp genes also identified the SSLB resistance corresponding to $R s p 1, R s p 2$, or $R s p 3$ in gene pyramiding $\mathrm{F}_{2}$ populations. The STS markers tightly linked to $R s p$ genes may be useful for MAS and for pyramiding with other genes in barley breeding for SSLB resistance.
\end{abstract}

Septoria speckled leaf blotch (SSLB) caused by the pathogen Septoria passerinii is an important leaf disease in barley (Hordeum vulgare L.) in the Upper Midwest region of the United States and in adjacent Canadian provinces. The disease was severe in the 1950s in the north central region of the United States and Prairie Provinces of Canada $(1,6)$, with yield losses of 23 to $38 \%$ reported in Canada (5). Recent SSLB-caused yield losses reported by Toubia-Rahme and Steffenson (20) are similar to those previously reported in Canada. The importance of SSLB is further increased due to its degradation of grain quality by reducing kernel size and malting quality (5). However, all of the major malting and feed barley cultivars in the Upper Midwest are susceptible to this pathogen. Development of resistant cultivars is the preferred method for preventing SSLB epidemics. SSLB resistance has been identified in different Hordeum accessions. The cvs. Atlas and Feebar and the accession CIho 4439 were identified as having SSLB resistance in Canada $(1,15,17)$. Seedling resistance in six-row barley CIho 4780 and CIho 14300, which are of northeast China origin, and CIho 10644, which is a selection from the cross Feebar/Kindred, was reported in the United States (18). In our previous work (14), the chromosome locations of Rsp genes for SSLB resistance were positioned on the genome of barley using three mapping populations, Robust/CIho 14300, Robust/CIho 4780, and Robust/CIho 10644. The resistant locus $R s p 1$ was mapped on the short arm of chromosome $3 \mathrm{H}$ and the genes $R s p 2$ and $R s p 3$ were mapped on the short arm of chromosome $1 \mathrm{H}$.

When breeding barley cultivars resistant to SSLB, it is necessary to have a reliable method of selection of plants containing a resistance gene. While conventional plant phenotype selection is straightforward, it is time-consuming, laborious, and

Corresponding author: S. M. Neate; E-mail address: Stephen.Neate@ndsu.edu

DOI: 10.1094/PHYTO-97-2-0162

(C) 2007 The American Phytopathological Society is sometimes inconclusive. SSLB is highly dependent on environmental conditions such as temperature and moisture (6) and develops most rapidly between 20 and $24^{\circ} \mathrm{C}$, and with more than $48 \mathrm{~h}$ of continuous moisture (2). Thus, screening of SSLB in the field in dry or hot seasons often fails due to unfavorable conditions for pathogen infection (6). As a result, it is critically important to develop more efficient and accurate techniques to identify SSLB resistant genotypes.

An alternative method of incorporating SSLB resistance into cultivars is by the use of molecular markers. Molecular markers are abundant and essentially independent from environmental conditions, and all stages of plant growth can be screened using these markers (11). Marker-assisted selection (MAS) also allows plant breeders to bypass laborious and costly phenotypic screens. Gene pyramiding can be difficult using conventional breeding methods due to the dominance and epistasis effects of genes governing disease resistance, and genes with similar reactions to two or more races are difficult to identify and transfer. However, the availability of molecular markers closely linked with each of the resistance genes makes the identification of plants with two or more genes possible (19).

Random amplified polymorphic DNA (RAPD) (23) has been widely used for genetic mapping and tagging many agriculturally important genes. However, this technique's main disadvantage is poor reliability and reproducibility, and its sensitivity to experimental conditions (10). Moreover, this technique has a limited use when trying to amplify a specific marker across different genetic backgrounds, because short random RAPD primers amplify several genetic loci (9). An alternative procedure to increase the reproducibility of the RAPD technique is to convert RAPD markers to sequence-characterized amplified region (SCAR) or sequence-tagged site (STS) markers. Identification of molecular markers for $R s p$ genes in the barley genome can improve the efficiency of MAS to develop SSLB-resistant cultivars and has the potential to assemble favorable gene combinations for SSLB control. 
In the present study, we report on (i) identification of RAPD markers linked to $R s p 1, R s p 2$, and Rsp3 SSLB-resistant genes, (ii) conversion of these markers into highly reproducible STS markers, (iii) evaluation of the STS markers in other barley accessions and germplasm in order to identify new SSLB resistance resources, and (iv) evaluation of the selection efficacy of STS markers in the field using $\mathrm{F}_{2: 3}$ families from the Robust/CIho 14300, Robust/CIho 4780, and Robust/CIho 10644 crosses.

\section{MATERIALS AND METHODS}

Plant materials. Six $\mathrm{F}_{2}$ populations were created from the sixrowed susceptible/resistant malting barley crosses Robust or Foster with CIho 14300, CIho 4780, or CIho 10644 as described in Lee and Neate (14). CIho 14300 (containing Rsp1) and CIho 4780 (containing $R s p 2$ ) are varieties of northeast China origin, and CIho 10644 (containing Rsp3) is a selection from the cross Feebar/Kindred (18).

The $\mathrm{F}_{2}$ generation (between 100 and 120 plants) was evaluated for SSLB at the seedling stage in the greenhouse and the adult stage in the field. $\mathrm{F}_{2-3}$ families (10 individuals) were planted in the greenhouse in the winter of 2004 to assess their seedling resistance to SSLB. To determine adult-stage SSLB resistance, three Robust $\mathrm{F}_{2-3}$ families (20 individuals for each line) were sown in the summer of 2004 in the field at two locations, Langdon and Osnabrock, ND, with two replications using an augmented block design (3).

To validate use of STS markers to pyramid Rsp genes, another series of crosses was made to pyramid $R s p$ genes in the winter of 2004 in the greenhouse. CIho 4780 (Rsp2) was used as the female parent in crosses with CIho 14300 (Rsp1) and CIho 10644 (Rsp3), and CIho 14300 was used as the female parent to cross with CIho 10644. $F_{1}$ plants were selfed to obtain $F_{2}$ segregating populations, and the $F_{2}$ populations were grown in the greenhouse to determine SSLB reactions in 2004.

SSLB inoculation in the greenhouse and field. Inoculation procedures for the SSLB assessment in both the greenhouse and the field followed the techniques described in Lee and Neate (14). A disease score of 0,1 , or 2 was regarded as resistant $(\mathrm{R})$ and a score of 3,4 , or 5 as susceptible $(\mathrm{S})$. Genes were termed segregating (SE) when $\mathrm{R}$ and $\mathrm{S}$ scores were present together in a plot.

Identification, cloning, and sequencing of RAPD markers. At the three-leaf stage, the first leaf was collected from each parent and progeny of the six $F_{2}$ populations grown in the greenhouse. Genomic DNA was extracted and then DNA quantification was performed by the method described in Lee and Neate (14). To identify RAPD markers associated with $R s p$ genes, SSLB-resistant and -susceptible DNA bulks were created consisting of equal amounts of DNA from five resistant and susceptible individual $\mathrm{F}_{2}$ plants. A total of 480 10-mer RAPD primers (obtained either from the University of British Columbia, Vancouver, Canada, or Operon Technologies Inc., Alameda, CA) were used to screen polymorphisms between the two different DNA bulks from resistant and susceptible $F_{2}$ plants, and between two susceptible parents and three resistant parents. The RAPD analysis was performed as described in Lee and Neate (14). The RAPD primers that amplified a polymorphic DNA fragment between resistant and susceptible bulks were selected and used for DNA amplification from parents and bulk individuals. The selected polymorphic RAPD primers were used to determine the genetic linkage between SSLB resistance genes and markers in six $\mathrm{F}_{2}$ and three $\mathrm{F}_{2-3}$ populations.

The identified RAPD markers for SSLB resistance genes were converted into STS markers for the analysis of both $\mathrm{F}_{2}$ plants and $\mathrm{F}_{2: 3}$ families. The polymorphic DNA fragments of RAPD markers were excised from agarose gel and purified using the
GENECLEAN kit (MP Biomedicals, Irvine, CA). The purified DNA fragments were inserted into the pCR 2.1-TOPO vector following the manufacturer's instructions. The cloning of the transformed plasmids was performed by using the TOPO TA cloning kit (Invitrogen, San Diego, CA). Restriction enzyme digestion using EcoRI was applied to determine if the correct size RAPD fragments were inserted into the plasmid. The plasmid DNAs containing the RAPD fragments were sequenced with the M13 reverse and forward primers with a Beckman-Coulter CEQ8000 DNA sequencer using dye-terminator chemistry at the Center for Biotechnology at the University of Nebraska, Lincoln. Specific pairs of 24- to 28-mer primers for $R s p 1, R s p 2$, and $R s p 3$ genes were designed on the basis of the sequencing data from RAPD fragments. All the STS primer pairs for this study were synthesized at Integrated DNA Technologies (Coralville, IA).

STS analysis. The designed primer pairs were tested in parents and DNA bulks to determine the presence or absence of STS markers linked to $R s p$ genes. The amplification of DNA was conducted in a $25-\mu$ l reaction mixture containing the same compositions and concentrations as used in the RAPD reactions, but with $10 \mathrm{pmol}$ of each reverse or forward STS primer. Two different polymerase chain reaction (PCR) conditions were used for the specific DNA amplification by STS markers linked to Rsp genes. The PCR program was one cycle of $5 \mathrm{~min}$ at $94^{\circ} \mathrm{C}, 31$ to 37 cycles (depending on the STS marker) of $30 \mathrm{~s}$ at $94^{\circ} \mathrm{C}, 1 \mathrm{~min}$ at optimum annealing temperature (various temperatures ranging from 53 to $62^{\circ} \mathrm{C}$ ), $1 \mathrm{~min}$ at $72^{\circ} \mathrm{C}$, and then the final step of $10 \mathrm{~min}$ at $72^{\circ} \mathrm{C}$. The amplified products, with $5 \mu$ l of loading buffer, were separated by electrophoresis using $1.5 \%$ agarose gel in $0.5 \times$ Trisborate-EDTA (TBE) buffer, and visualized under UV light.

Accuracy of genotypic identification to SSLB reactions. The DNA samples of field $\mathrm{F}_{2-3}$ plants were prepared to evaluate the selection accuracy of molecular markers for $R s p$ genes. DNA extraction from leaf samples followed the same protocol used in the RAPD analysis. The specific RAPD and STS markers for SSLB-resistant genes were tested on the DNA samples. The genotypic data obtained from marker analysis were compared with both greenhouse and field phenotypic data to calculate the rate of recombination between markers and the genes of interest.

Analysis of data. A chi-square goodness-of-fit test was applied to phenotypic data to check the fit of segregation classes. The linkage relationships between molecular markers and SSLB resistance genes were calculated using recombination frequencies, and were converted into approximate map distances (centimorgans) by using the Kosambi mapping function (13).

Evaluation of new SSLB resistance resources. The STS markers developed from RAPD markers were used to screen another 42 barley accessions of known resistance reaction to SSLB and 314 very diverse accessions of unknown resistance reaction to SSLB to determine the presence or absence of the STS markers linked to $R s p 1, R s p 2$, and $R s p 3$. Twenty-three putatively resistant and 19 putatively susceptible accessions to $S$. passerinii were selected based on a recent study by Toubia-Rahme and Steffenson (21). All the accessions except the parents used in this study were obtained from the National Small Grain Collection of the United States Department of Agriculture-Agricultural Research Service (USDA-ARS). Disease reactions of 42 barley accessions to $S$. passerinii were tested in the greenhouse in the winter of 2004. To identify new SSLB resistance resources, SSLB reactions of 314 accessions from the Centre for Genetic Resources, Wageningen, the Netherlands were planted in the greenhouse in April 2005. For all the greenhouse inoculation experiments, four plants per accession were planted in plastic cones filled with \#1 Sunshine Mix (Sun Gro Horticulture Canada Ltd., Alberta, Canada) (3:1 peat moss/perlite) and fertilized with Osmocote 14-14-14 (Scotts Company, Marysville, OH) (1 g/cone) and Peters 15-0-15 (Scotts Company) (180 g gal ${ }^{-1}$ concentrate). Plants were grown at $22 \pm 2{ }^{\circ} \mathrm{C}$ and $14 \mathrm{~h}$ photoperiod (430W high 
pressure sodium bulb lights, SonAgro Phillips, Somerset, NJ) in a greenhouse. Ten days after planting, inoculum was applied to plants using a DeVilbiss model 15 atomizer pressurized by an air pump $(100 \mathrm{kPa})$. Inoculation followed the same procedure as described earlier. SSLB infection was scored 17 days after inoculation. The Centre for Genetic Resources accessions showing high levels of resistance to SSLB were selected to evaluate the STS markers linked to Rsp genes.

\section{RESULTS AND DISCUSSION}

Identification of RAPD markers associated with Rsp genes. Among the 480 RAPD primers tested, 148 10-mer random primers were polymorphic between susceptible and resistant parents. Those primers were tested on DNA bulks to determine their association with $R s p$ genes. The RAPD primers that showed polymorphic bands and consistent amplification patterns in every parent and in $\mathrm{F}_{2}$ individuals were only included for the analysis of 100 to $120 \mathrm{~F}_{2}$ individuals. As a result, 15 RAPD markers were identified as associated with $R s p$ genes in the Robust $\mathrm{F}_{2}$ populations on the basis of linkage analysis. However, only the markers $\mathrm{UBC} 285_{158 \mathrm{R}}, \mathrm{OPC} 2_{441 \mathrm{R}}, \mathrm{OPAH} 5_{545 \mathrm{C}}, \mathrm{OPBA} 12_{314 \mathrm{C}}$, and OPB $17_{451 \mathrm{R}}$, linked to an $R s p$ gene by $5.0 \mathrm{cM}$ or less, were included for further study, because they can be effectively used for indirect selection (22). The coupling phase markers were present in only resistant lines, and the repulsion phase markers were absent in homozygous resistant lines.

Linkage analysis revealed RAPD markers UBC285 $158 \mathrm{R}$ $(4.3 \mathrm{cM})$ and $\mathrm{OPC}_{441 \mathrm{R}}(3.0 \mathrm{cM})$ in repulsion linked to $R s p 1$; RAPD marker OPAH5 $545 \mathrm{C}$ in coupling linked to Rsp2 with no recombination; and RAPD marker OPBA12 $2_{314 \mathrm{C}}(2.4 \mathrm{cM})$ linked in coupling, and $\mathrm{OPB} 17_{451 \mathrm{R}}(3.5 \mathrm{cM})$ linked in repulsion, to Rsp3. $\mathrm{UBC} 285_{158 \mathrm{R}}, \mathrm{OPC} 2_{441 \mathrm{R}}, \mathrm{OPB} 17_{451 \mathrm{R}}$, OPAH5 $5_{545 \mathrm{C}}$, and OPBA $12_{314 \mathrm{C}}$ showed the expected segregation ratio of 1 resistant:3 susceptible or 3 resistant: 1 susceptible for band presence to band absence in $\mathrm{F}_{2}$ plants derived from Robust crossed to a resistant line each containing one of the Rsp genes (Table 1). Two RAPD markers $\left(\mathrm{UBC} 285_{158 \mathrm{R}}\right.$ and OPAH5 $545 \mathrm{C}$ ) were tested on other $\mathrm{F}_{2}$ populations derived from Foster/CIho 14300 or Foster/CIho 4780. UBC285 $158 \mathrm{R}$ was $4.6 \mathrm{cM}$ from $R s p 1$, similar to the genetic distance found in the Robust population. The closest marker linked to $R s p 2$, OPAH5 $5_{545 \mathrm{C}}$, was at $0.9 \mathrm{cM}$ in the Foster/CIho $4780 \mathrm{~F}_{2}$ population. This indicates that $\mathrm{OPAH} 5_{545 \mathrm{C}}$, which showed no recombination with $R s p 2$ in the Robust/CIho $4780 \quad \mathrm{~F}_{2}$ population, is probably not located within the gene of interest, but is still tightly linked to Rsp2.

STS markers linked to $R s p$ genes. To overcome the limitations of RAPD techniques in MAS, RAPD markers associated with $R s p$ genes were converted into STS markers SUBC285, SOPC2, SOPAH5, and SOPBA12 (Fig. 1). The conversion of RAPD markers into STS markers was successful, indicating that developing sequence-specific markers from RAPD primers is an efficient process for barley. Most of the STS markers amplified the same sized band as the original RAPD polymorphism from resistant and susceptible individuals and no recombination event was found in the three Robust $\mathrm{F}_{2-3}$ populations. The STS markers SUBC285 and SOPC2 (linked to $R s p 1$ ) and SOPBA12 (linked to Rsp3) were developed by designing the specific forward and reverse 24-mer primers on the basis of the sequences of RAPD fragments following the original 10 -mer sequence of RAPD primers (Table 2). The repulsionphase STS markers SUBC285 and SOPC2 linked to Rsp 1 produced a specific amplified band only in the two susceptible cultivars, Robust and Foster, and in the susceptible bulk individuals. The coupling-phase STS marker SOPBA12 was only present in the resistant line containing $R s p 3$, CIho 10644, $\mathrm{F}_{1}$ plants, and the resistant bulk $\mathrm{F}_{2}$ individuals.

To develop the marker SOPAH5 for Rsp2, two primers were designed from the OPAH $5_{545 \mathrm{C}}$-amplified sequence following the previous protocol. However, the specific primers for SOPAH5 obtained from each end of the OPAH5 sequence amplified a fragment in both susceptible and resistant individuals. The loss of polymorphism may be due to mismatches in one or a few nucleotides at the primer binding site of the original RAPD marker (16). This problem was solved by sequencing the amplified resistant and susceptible parents and searching for polymorphic regions in the internal sequence between resistant and susceptible fragment. Several single nucleotide polymorphisms were identified between the susceptible and resistant sequence and two STS primers were synthesized that amplified a specific band in only the resistant genotype. The STS marker SOPAH5 showed a major band in only the resistant parent and in $\mathrm{F}_{2}$ bulk individuals containing $R s p 2$, but was absent in susceptible parents and the bulk individuals. Based on our previous work on molecular mapping of $R s p$ genes, $R s p 2$ and $R s p 3$ are closely linked on the short arm of chromosome $1 \mathrm{H}$ in barley (14). To identify other STS markers linked to Rsp 2 and Rsp3 genes, STS markers mapped on the short arm of chromosome $1 \mathrm{H}$ were selected from GrainGenes database (provided online by the USDA), and primers were constructed and tested in susceptible and resistant parents. Markers showing polymorphisms between parents were screened on DNA bulks and $\mathrm{F}_{2}$ individuals. MWG938, co-segregated with DNA bulks and segregation analysis in the $\mathrm{F}_{2}$ Robust/CIho 4780 population, showed no recombination with Rsp2 (Table 1).

Selection accuracy of STS markers in MAS. To test the selection accuracy of STS markers in MAS for a single Rsp gene, the field DNA samples from three Robust $\mathrm{F}_{2-3}$ populations were screened with SUBC285, SOPC2, SOPAH5, MWG938, or SOPB12. Three RAPD markers (UBC285, OPAH5, and OPBA12) were also tested for recombination between RAPD and STS markers in $\mathrm{F}_{2-3}$ populations. Correlation between disease resistance in the greenhouse and the existence of STS markers for resistance genes $R s p 1, R s p 2$, or $R s p 3$ was high. The STS markers

TABLE 1. Segregation analysis using random amplified polymorphic DNA markers linked to Rsp genes in three $\mathrm{F}_{2}$ populations from crosses of the susceptible cv. Robust and the barley accessions CIho 14300, CIho 4780, and CIho 10644 resistant ${ }^{\mathrm{a}}$ to Septoria speckled leaf blotch

\begin{tabular}{|c|c|c|c|c|c|c|c|c|}
\hline \multirow{2}{*}{$\frac{\text { Population }}{\text { Robust/CIho } 14300}$} & \multirow{2}{*}{$\frac{\text { Gene }}{\text { Rsp } 1}$} & Marker & \multicolumn{2}{|c|}{ Genotype $^{b}$} & \multirow{2}{*}{$\begin{array}{c}\begin{array}{c}\text { Expected } \\
\text { segregation }\end{array} \\
1: 3 \\
1: 3\end{array}$} & \multirow{2}{*}{$\begin{array}{c}\chi^{2} \\
0.55 \\
0.05\end{array}$} & \multirow{2}{*}{$\begin{array}{c}P^{\mathrm{c}} \\
0.46 \\
0.82\end{array}$} & \multirow{2}{*}{$\begin{array}{c}\text { Genetic distance }(\mathrm{cM}) \\
4.3 \\
3.0\end{array}$} \\
\hline & & $\begin{array}{l}\text { UBC } 285_{158 \mathrm{R}} \\
\mathrm{OPC} 2_{441 \mathrm{R}}\end{array}$ & $\begin{array}{l}22 \text { (RR) } \\
24 \text { (RR) }\end{array}$ & $\begin{array}{l}81(\mathrm{Rr} / \mathrm{rr}) \\
78(\mathrm{Rr} / \mathrm{rr})\end{array}$ & & & & \\
\hline Robust/CIho 4780 & Rsp2 & $\begin{array}{l}\text { OPAH5 }_{545 \mathrm{C}} \\
\text { MWG938 }\end{array}$ & $\begin{array}{l}75 \text { (R-) } \\
75 \text { (R-) }\end{array}$ & $\begin{array}{l}25(\mathrm{rr}) \\
25(\mathrm{rr})\end{array}$ & $\begin{array}{l}3: 1 \\
3: 1\end{array}$ & $\begin{array}{l}0.00 \\
0.00\end{array}$ & $\begin{array}{l}1.00 \\
1.00\end{array}$ & $\begin{array}{l}0.0 \\
0.0\end{array}$ \\
\hline Robust/CIho 10644 & Rsp3 & $\begin{array}{l}\text { OPBA } 12_{314 \mathrm{C}} \\
\text { OPB } 17_{451 \mathrm{R}}\end{array}$ & $\begin{array}{l}84 \text { (R-) } \\
24 \text { (RR) }\end{array}$ & $\begin{array}{l}29(\mathrm{rr}) \\
87(\mathrm{Rr} / \mathrm{rr})\end{array}$ & $\begin{array}{l}3: 1 \\
1: 3\end{array}$ & $\begin{array}{l}0.03 \\
0.51\end{array}$ & $\begin{array}{l}0.87 \\
0.48\end{array}$ & $\begin{array}{l}2.4 \\
3.5\end{array}$ \\
\hline
\end{tabular}

\footnotetext{
a Resistance was evaluated in the greenhouse at Fargo, ND, in 2004.

${ }^{\mathrm{b}} \mathrm{RR}$, homozygous resistant; R-, homozygous resistant or heterozygous; Rr, heterozygous; and rr, homozygous susceptible.

c $P<0.05=$ significant deviation from the expected segregation ratio.

${ }^{\mathrm{d}}$ Genetic distance (centimorgans) was determined by MAPMAKER (Whitehead Inst. for Biomedical Res., Cambridge, MA) using log 10 odds ratio > 3.0.
} 
linked to Rsp genes produced the expected size of fragments for three populations containing $R s p 1, R s p 2$, or $R s p 3$ genes, and were found to co-segregate fully with RAPD markers in the populations (Fig. 2). SOPC2 and SUBC285 linked to Rsp1 were tested on the $\mathrm{F}_{2-3}$ population derived from Robust and CIho 14300 , but only SOPC 2 data are included in Table 3 because of its close linkage to Rsp 1 . Five recombinants were found between SOPC2 and SUBC285, but the selection efficiency for SSLB reaction phenotype by SUBC285 was not significantly different from SOPC2. SOPC2 predicted the correct SSLB reaction phenotype with an accuracy of $97 \%$ in the greenhouse, $98 \%$ in the Langdon field trial, and $99 \%$ in the Osnabrock field trial in the $\mathrm{F}_{2-3}$ populations. The markers SOPAH5 and MWG938, closely linked to $R s p 2$, predicted SSLB reaction phenotype with $100 \%$ accuracy in the greenhouse, 98\% accuracy in Langdon, and 90\% accuracy in Osnabrock. SOPBA12 predicted SSLB reaction phenotype with $97 \%$ accuracy in the greenhouse, $98 \%$ in Langdon, and $97 \%$ in Osnabrock. Dominant STS markers linked to $R s p$ genes are not able to identify heterozygous resistant individuals, but both coupling and repulsion phase markers identified homozygous resistant and susceptible individuals effectively (Table 3).

The decreased accuracy of SOPAH5 and MWG938 achieved in the field at Osnabrock may be due to disease escape in segregating and susceptible progeny, as high selection efficiency was achieved in the greenhouse and in the field at Langdon. In SOPC2 (which is linked to Rsp1) and SOPBA12 (which is linked to $R s p 3$ ) phenotypic and genotypic data did not match in three
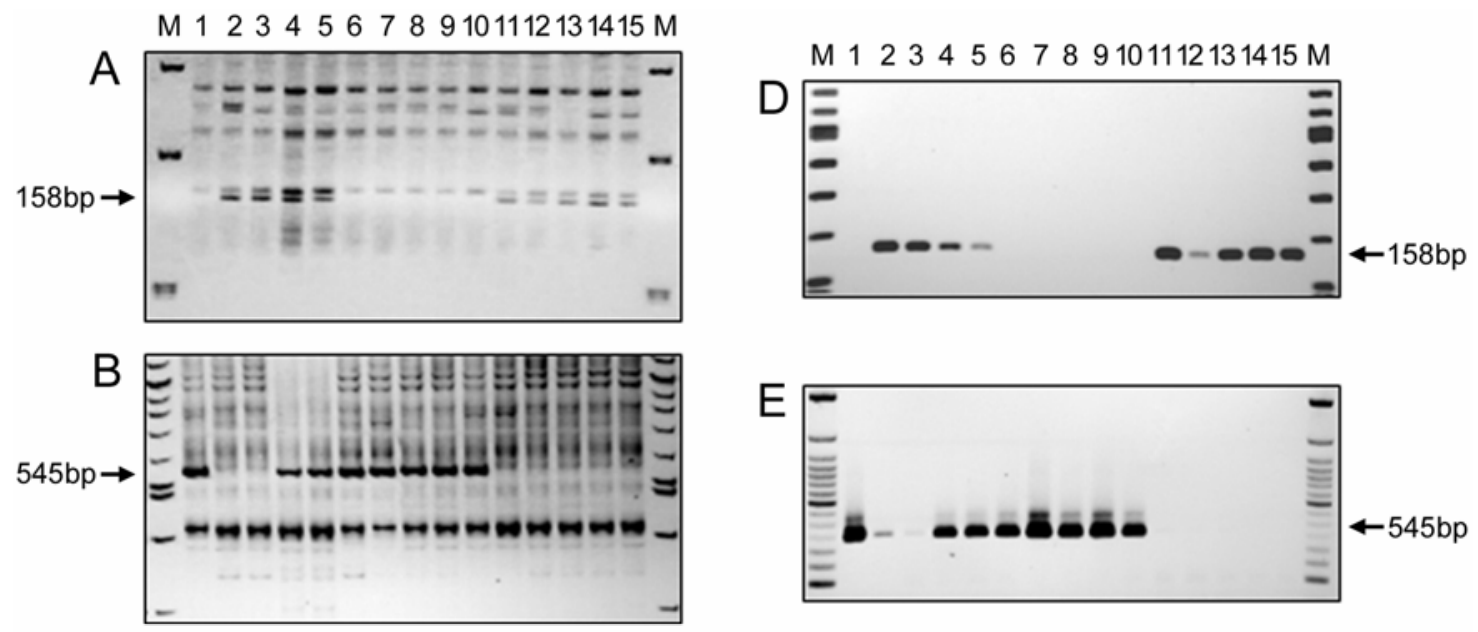

E
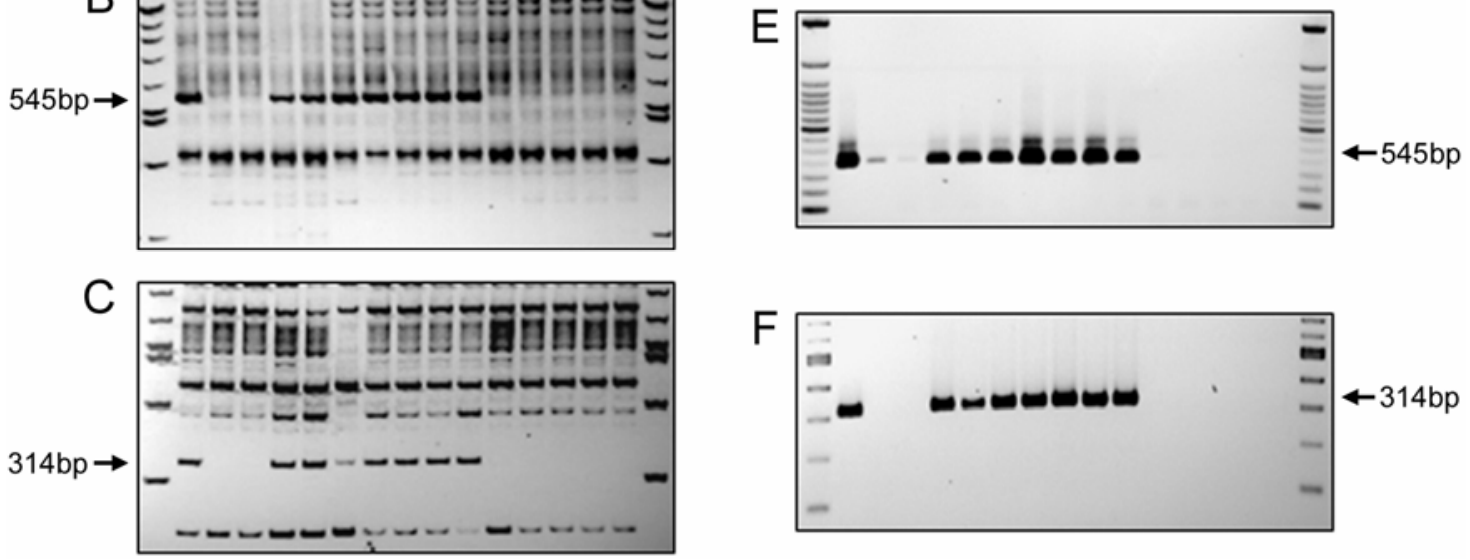

Fig. 1. Identification of polymorphisms associated with Septoria speckled leaf blotch resistance genes $R s p 1$, Rsp2, and Rsp3, using random amplified polymorphic DNA (RAPD) markers A, UBC $285_{158 R}, \mathbf{B}, \mathrm{OPAH} 5_{545 \mathrm{C}}$, and $\mathbf{C}$, OPBA $12_{314 \mathrm{C}}$. The RAPD markers were converted into sequence tagged site markers $\mathbf{D}$, SUBC285, E, SOPAH5, and F, SOPBA12. Lanes are as follows: M, DNA size marker; lane 1, resistant parent CIho 14300 (A and D), CIho 4780 (B and E), and CIho 10644 (C and F); lane 2, susceptible parent Robust; lane 3, susceptible parent Foster; lane 4, F1 plant of Robust/CIho 14300 (A and D), CIho 4780 (B and E), and CIho 10644 (C and F); lane 5, F 1 plant of Foster/CIho 14300 (A and D), CIho 4780 (B and E), and CIho 10644 (C and F); lanes 6 through 10, $\mathrm{F}_{2}$-resistant individuals; lanes 11 through $15, \mathrm{~F}_{2}$-susceptible individuals.

TABLE 2. Septoria speckled leaf blotch of barley resistance gene-specific random amplified polymorphic DNA (RAPD) primer sequences and sequence tagged site primer pair sequences derived from cloned RAPD fragments

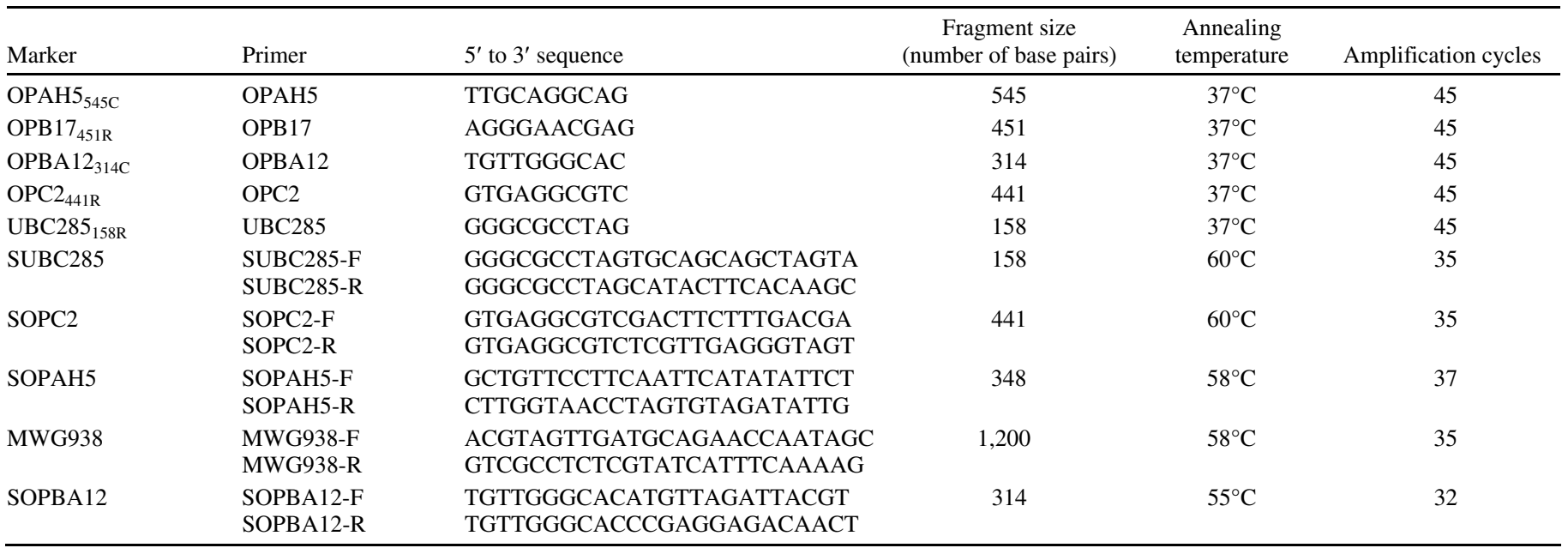


progeny, possibly due to recombination between the resistance gene and its marker in those progeny, as the markers are predicted to be $3.0 \mathrm{cM}$ from $R s p 1$ and $2.4 \mathrm{cM}$ from $R s p 3$.

Evaluation of STS markers in gene pyramiding of $R \boldsymbol{s p}$ genes. The disease reactions of 116 (CIho 14300/CIho 4780) and 123 (CIho 4780/CIho 10644) $\mathrm{F}_{2}$ plants inoculated with $S$. passerinii were investigated in the greenhouse. In the $\mathrm{F}_{2}$ population derived from CIho 14300/CIho 4780, nine plants were susceptible to SSLB. However, all $\mathrm{F}_{2}$ plants from the cross CIho 4780/CIho 10644 were resistant against $S$. passerinii (Table 4). This significant deviation from the expected segregation ratio of 15:1 supports previous research showing that the two genes $R s p 2$ and Rsp3 may be linked together (14). To evaluate the use of the markers in pyramided lines, five STS markers, SUBC285, SOPC2, SOPAH5, MWG938, and SOPBA12, were used to predict SSLB resistance loci in the Rsp gene pyramided lines. A high level of selection accuracy of MAS for Rsp genes in the gene pyramided $\mathrm{F}_{2}$ populations was achieved in this study. Based on marker genotypes, plants were found to carry one or two Rsp genes, and all plants containing at least one $R s p$ gene showed a resistant reaction to SSLB in both populations (Fig. 3).

Two markers linked to $R s p 1$ in repulsion, SOPC2 and SUBC285, effectively detected homozygous resistance genotypes in the $\mathrm{F}_{2}$ population of the CIho 14300/CIho 4780 cross (Fig. 3). However, those markers were unable to separate heterozygous resistant and homozygous susceptible lines in the $F_{2}$ population

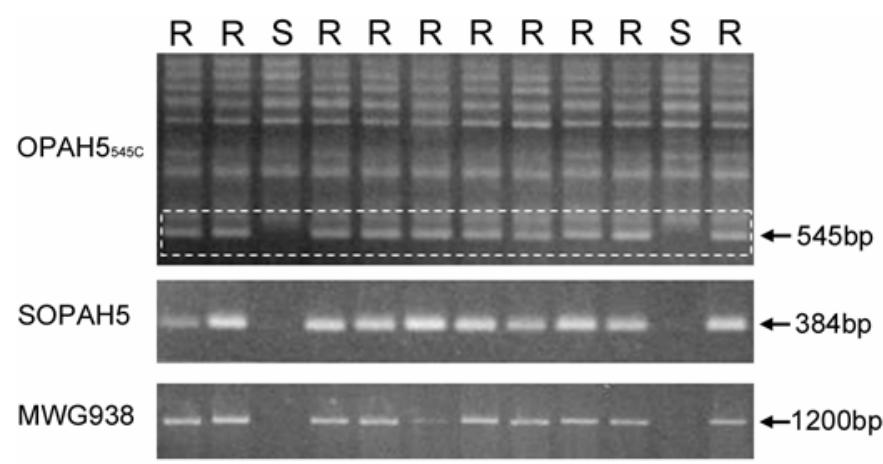

Fig. 2. Segregation of random amplified polymorphic DNA marker OPAH5 $545 \mathrm{C}$ and sequence tagged site markers SOPAH5 and MWG938, linked to $R s p 1$ in a $\mathrm{F}_{2-3}$ population derived from Robust/CIho 4780 . The polymerase chain reaction-amplified products were separated on $1.5 \%$ agarose gel and visualized under ultraviolet light after ethidium bromide staining.
(Fig. 3). All nine susceptible plants in CIho 14300/CIho 4780 contained SUBC285 and SOPC2, but not SOPAH5. A marker linked to the susceptible allele of the resistant locus can greatly increase selection efficiency through the selection of heterozygous resistant and susceptible genotypes, which can lead to an increase of selection of homozygous resistant genotypes $(7,12)$.

The combination of SOPAH5 and MWG938 linked to Rsp2 and SOPBA12 linked to Rsp3 in coupling correctly predicted SSLB reactions for the homozygous/heterozygous resistant and susceptible progeny of the $\mathrm{F}_{2}$ population CIho 4780/CIho 10644. No recombinants were observed between the genotype of MWG938 and SOPAH5. Thus, the two markers are not only tightly linked to $R s p 1$, but also each other in the $F_{2}$ population. Moreover, an allelism test of the population based on plant phenotypic and marker genotypic data closely agrees with our previous study in that $R s p 2$ and $R s p 3$ are closely linked on the short arm of chromosome $1 \mathrm{H}$ (14).

Evaluation of STS markers in barley germplasm. To determine the existence of STS markers linked to Rsp genes, 23 resistant and 19 susceptible barley lines identified as resistant or susceptible to SSLB by Toubia-Rahme and Steffenson (21) were evaluated (Table 5). All germplasm was inoculated and screened for resistance to SSLB in a greenhouse. Five STS markers linked to $R s p$ genes were tested to determine the correlation of the presence of markers with the presence of SSLB resistance. SUBC285, SOPC2, SOPAH5, and MWG938 showed the expected presence or absence of bands in resistant lines. However, markers were also found in 3/19 (SUBC285)-, 7/19 (SOPC2)-, 8/19 (SOPAH5)-, and 10/19 (MWG938)-susceptible lines. The STS marker SOPBA12, linked to $R s p 3$ at a distance of $2.3 \mathrm{cM}$, in all cases correctly identified resistant lines. SOPBA12 amplified a band only in the four resistant lines Bolron, Feebar, Flynn1, and Vaughn.

SUBC285 and SOPC2 also gave some unexpected results, with 12 of 23 resistant and 10 of 18 susceptible lines giving different results for the two markers (Table 5). The recombination of $R s p 1$ with either of the two marker sequences for SUBC285 (4.3 cM) and SOPC2 (3.0 $\mathrm{cM})$ may have resulted in the detection of one marker but not the other in some accessions (Table 5).

SOPAH5 and MWG938, both linked with no recombination to $R s p 2$ in the $\mathrm{F}_{2}$ Robust/CIho 4780 population, gave different results for the two markers in 4 of 23 resistant and 8 of 18 susceptible lines (Table 5). This result indicates that the markers may not be located inside of the Rsp 2 gene, but are close by, and recombination of the gene with the markers may have resulted in detection of the

TABLE 3. Selection efficacy of sequence tagged site (STS) markers associated with Septoria speckled leaf blotch of barley resistance genes in $\mathrm{F}_{2-3}$ populations derived from the crosses Robust/CIho 14300 (Rsp1), Robust/CIho 4780 (Rsp2), and Robust/CIho 10644 (Rsp3). Resistance was evaluated in the field at Langdon and Osnabrock, ND, in 2004

\begin{tabular}{|c|c|c|c|c|c|c|}
\hline \multirow[b]{2}{*}{ Location } & \multirow[b]{2}{*}{ Gene } & Phenotype $^{\mathrm{a}}$ & SOPAH5/ & $\mathrm{SOPC}^{\mathrm{c}}$ & SOPBA $12^{b}$ & \multirow[b]{2}{*}{ Selection accuracy } \\
\hline & & RR:Rr:rr & R-:rr & RR:R- & R-:rr & \\
\hline \multirow[t]{2}{*}{ Greenhouse } & $R s p 1$ & $18: 46: 21$ & & $15: 70$ & $\ldots$ & $97 \%$ \\
\hline & Rsp3 & $21: 45: 30$ & $\ldots$ & $\ldots$ & $69: 27$ & $97 \%$ \\
\hline \multicolumn{7}{|l|}{ Field } \\
\hline Langdon ${ }^{\mathrm{e}}$ & $R s p 1$ & $17: 41: 27$ & & $15: 70$ & $\ldots$ & $98 \%$ \\
\hline \multirow[t]{3}{*}{ Osnabrock $^{\mathrm{e}}$} & Rsp 1 & $16: 42: 27$ & . & $15: 70$ & $\ldots$ & $99 \%$ \\
\hline & Rsp2 & $30: 52: 15$ & $72: 25$ & $\ldots$ & $\ldots$ & $89 \%$ \\
\hline & Rsp3 & $19: 53: 24$ & $\ldots$ & $\ldots$ & $69: 27$ & $97 \%$ \\
\hline
\end{tabular}

a RR, homozygous resistant; R-, homozygous resistant or heterozygous; Rr, heterozygous; and rr, homozygous susceptible.

${ }^{b}$ Markers in the coupling phase, and the expected segregation ratio is $3: 1$.

${ }^{c}$ Markers in the repulsion phase, and the expected segregation ratio is 1:3.

$\mathrm{d}$ The percentage of selection accuracy of STS markers in marker-assisted selection.

e Field locations in North Dakota. 
marker fragments in susceptible cultivars without Rsp2 genes. The STS marker linked to Rsp2, MWG938, was also present in CIho 14300, which is known to contain only one functional resistance gene, Rsp 1 . Previous work (14) has shown that Rsp 1 and $R s p 2$ are unequivocally on two different chromosomes. It is likely that MWG938 is recognizing a sequence outside of $R s p 2$ that is present in CIho 14300. As both resistant accessions were collected from Heilongjiang, China, in 1963, they may have a similar genetic background.

SOPBA12 linked to Rsp3 was detected in only five resistant barley-breeding germplasm lines and one landrace (Tables 5 and 6). The pedigree of CIho 10644 (which contains Rsp3) is Feebar/Kindred. The pedigree of Feebar is Peatland (susceptible)/Vaughn (resistant) and the pedigree of Vaughn is Mariout/Leiorrhynchium or Club Mariout/Lion (GrainGenes database). Flynn also comes from a cross between Club Mariout/Lion, and Flynn1 is a selection from Flynn. ToubiaRahme and Steffenson (21) reported that the barley line Mariout originated from Egypt and is believed to be the probable source of resistance to $S$. passerinii for resistant lines Feebar, Vaughn, Flynn1, and CIho 10644. This result gives hope that with further testing, the STS marker SOPBA12 can be effectively used in MAS to identify lines containing Rsp3. The other line testing positive to SOPBA12, Bolron, is from a cross Bolivia/Chevron, and has a different genetic background. Bolivia is resistant to SSLB while Chevron is susceptible to SSLB (21). Thus, Bolivia is the probable source of SSLB resistance in Bolron (Table 5).

In a search of BLAST (BLASTN 2.3.13, NCBI), the sequence of the OPBA12 $314 \mathrm{C}$ fragment used to develop SOPBA12 showed a $97 \%$ homology with a receptor-like kinase ARK1AS gene described by Feuillet and Keller (4) in H. vulgare subsp. vulgare. This type of gene receptor-like kinase is associated with disease resistance in plants (8). The locus of a receptor-like kinase gene cluster has been found on chromosome $1 \mathrm{H}$ in barley (8) and we showed that Rsp3 is located on chromosome 1HS (14).

From STS marker evaluation in barley-breeding germplasm, SOPBA12 seems to be the most suitable marker for MAS. The repulsion phase markers SUBC285 and SOPC2 (for Rsp1) and the coupling phase markers SOPAH5 and MWG938 (for Rsp2) were not able to clearly distinguish between the different resistant and susceptible barley-breeding germ plasm with $100 \%$ accuracy. Further testing of these markers in populations of diverse genetic background and known SSLB resistance genes is necessary to determine the markers' effectiveness. The SSLB resistant lines Atlas54 and Glacier did not show any of the markers associated with the known resistance genes and thus may contain other resistance genes. Peterson (17) described that Atlas possesses dominant resistance genes to $S$. passerinii, but no molecular genetic study has been conducted to confirm this finding.

Evaluation of STS markers in barley landraces. A total of $98(31 \%)$ of 314 accessions tested from the Centre for Genetic Resources was found to possess a high level of resistance to $S$. passerinii (infection reaction of 0 to 1 ) using isolates ND03190 and ND03338 (Table 6). The susceptible check Foster exhibited a susceptible reaction type (3 to 5) and the resistant checks CIho 14300, CIho 4780, and CIho 10644 exhibited resistant type reactions (0 to 1 ). About 61\% (59 out of 68) of all resistant accessions originating from Ethiopia were resistant to S. passerinii. A total of 12 of $109(11 \%)$ accessions originating from Pakistan were also resistant (Table 6). Three STS markers, SOPAH5, MWG938, and SOPBA12, were tested to predict the existence of possible resistance alleles at $R s p$ loci in the 98 accessions resistant to $S$. passerinii. The STS markers in repulsion for $R s p 1$, SUBC285 and SOPC2, were not included as

TABLE 4. Identification of sequence tagged site (STS) markers associated with Septoria speckled leaf blotch (SSLB) of barley resistance ${ }^{\mathrm{a}}$ genes for $R s p 1$ and $R s p 2$ genes in $\mathrm{F}_{2}$ from the crosses CIho 14300/CIho 4780 and CIho 4780/CIho 10644 where CIho 14300 contained Rsp 1, CIho 4780 contained Rsp2, and CIho 10644 contained $R s p 3$

\begin{tabular}{|c|c|c|c|c|c|c|}
\hline & $\begin{array}{c}\text { Observed } \\
\text { SSLB }\end{array}$ & $\begin{array}{l}\text { Expected } \\
\text { SSLB }\end{array}$ & & & & \\
\hline Cross & $\mathrm{R}$-:rr & $\mathrm{R}$-:rr & $P^{\mathrm{b}}$ & Observed STS marker ${ }^{\mathrm{c}}$ & Expected STS marker & $P$ \\
\hline CIho $14300 /$ CIho 4780 & $107: 9$ & $15: 1$ & 0.63 & $65: 19: 22: 10^{\mathrm{d}}$ & $10: 3: 2: 1^{\mathrm{d}}$ & 0.11 \\
\hline
\end{tabular}

${ }^{a}$ Resistance was evaluated in the greenhouse at Fargo, ND, in 2004.

${ }^{\mathrm{b}} P<0.05=$ significant deviation from the expected segregation ratio; $P>0.05=$ fit to the expected segregation ratio of the $\mathrm{F}_{2}$ population.

${ }^{c}$ SOPC2 was analyzed for CIho 14300/CIho 4780, and SOPAH5 and MWG938 were used for the analysis of CIho 4780/CIho 10644.

d Ratio of R1-R2-, R1-r2 : r1R2-, r1r2 : R1-R2 : r1R2.

${ }^{e}$ Ratio of R1-R2-: R1-r2 : r1R2- : r1r2.

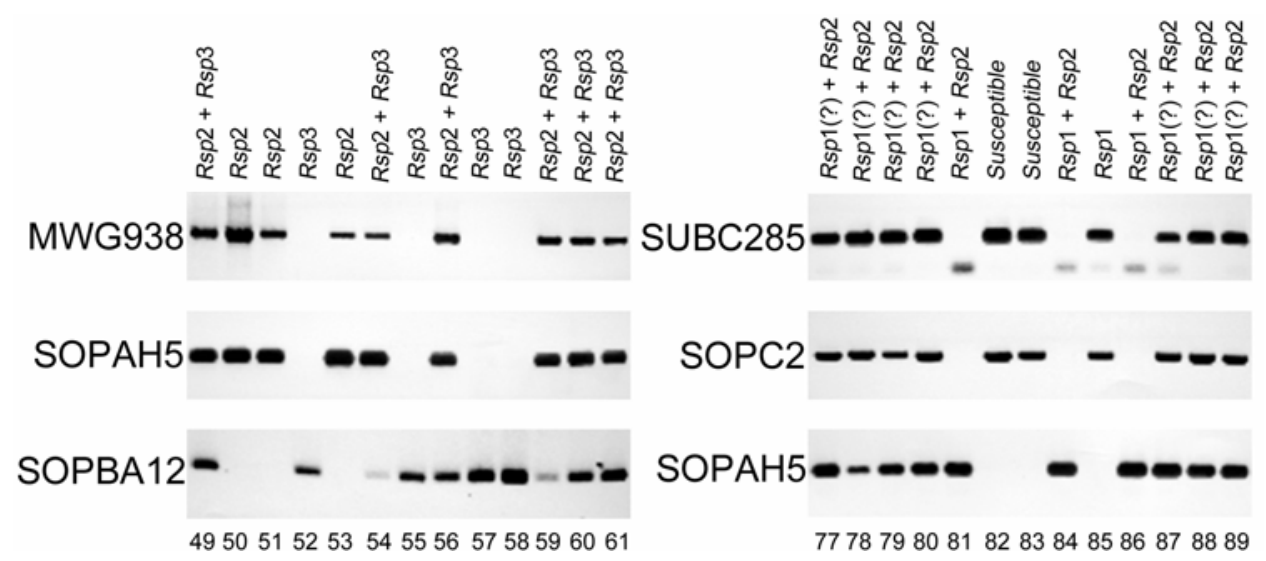

Fig. 3. The analysis of sequence tagged site markers linked to $R s p 1, R s p 2$, and $R s p 3$ genes for Septoria speckled leaf blotch (SSLB) resistance in gene pyramiding $\mathrm{F}_{2}$ populations CIho 4780 (Rsp2)/CIho 10644 (Rsp3) and CIho 14300 (Rsp1)/CIho 4780 (Rsp2). SUBC285 and SOPC2 linked to Rsp1, MWG938 and SOPAH5 linked to $R s p 2$, and SOPBA12 linked to $R s p 3$ were used to predict genotypes in two $\mathrm{F}_{2}$ populations. The possession of $R s p 1$ in the $\mathrm{F}_{2}$ progeny of 77,78 , 79, 80 , 87,88 , and 89 was not identified by SUBC285 and SOPC2. The presence of $R s p 1$ in the $\mathrm{F}_{2}$ progeny of 82,83 , and 85 was determined by comparison with the SSLB phenotypic data. 
they identify both heterozygous and homozygous susceptible lines and are less informative than markers in coupling. Furthermore, the absence of bands in the resistant accessions may not directly indicate the presence of $R s p 1$. A total of 29 resistant accessions showed STS markers associated with $R s p$ genes: 8 for SOPAH5, 20 for MWG938, and 1 for SOPBA12. Only 8 of 59 resistant accessions originating from Ethiopia had either SOPAH5 or MWG938 markers. Five of eight resistant accessions corresponding with SOPAH5 also showed the presence of the marker MWG938 (Table 6). Marker SOPBA12, linked to Rsp3, was only found in one resistant line from Pakistan.

In conclusion, we have developed five new STS markers and identified another previously identified marker that all closely link to Rsp genes conferring SSLB resistance in barley in our populations. These markers have potential for use in MAS in breeding barley with SSLB resistance but still require further

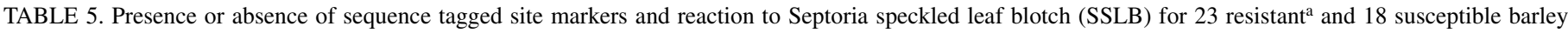
genotypes

\begin{tabular}{|c|c|c|c|c|c|c|c|c|c|}
\hline $\begin{array}{l}\text { Cultivars/ } \\
\text { breeding } \\
\text { lines }\end{array}$ & $\begin{array}{l}\text { Reaction } \\
\text { to } \text { SSLB }^{\text {b }}\end{array}$ & $\begin{array}{c}\text { SUBC285 } \\
\text { /SOPC2 }\end{array}$ & $\begin{array}{l}\text { SOPAH5/ } \\
\text { MWG938 }\end{array}$ & SOPBA12 & Cultivars/lines & $\begin{array}{l}\text { Reaction } \\
\text { to SSLB }\end{array}$ & $\begin{array}{c}\text { SUBC285 } \\
\text { /SOPC2 }\end{array}$ & SOPAH5/MWG938 & SOPBA12 \\
\hline Atlas54 & $\mathrm{R}$ & $-/-^{c}$ & $-1-$ & - & Sussex & $\mathrm{R}$ & $+/+$ & $-1-$ & - \\
\hline Atlas & $\mathrm{R}$ & $+/-$ & $-1-$ & - & Vaughn & $\mathrm{R}$ & $+/-$ & $-1-$ & + \\
\hline Bolron & $\mathrm{R}$ & $+/+$ & $-1+$ & + & Adlesici & $\mathrm{S}$ & $-1+$ & $+/+$ & - \\
\hline CIho 4428 & $\mathrm{R}$ & $-1+$ & $-1-$ & - & Bowman & $\mathrm{S}$ & $-1-$ & $+/+$ & - \\
\hline CIho 4439 & $\mathrm{R}$ & $-1-$ & $+/+$ & - & Carlsberg & $\mathrm{S}$ & $-1+$ & $-1+$ & - \\
\hline CIho 4780 & $\mathrm{R}$ & $-1-$ & $+/+$ & - & CIho 4753 & $\mathrm{~S}$ & $-1-$ & $+/-$ & - \\
\hline CIho 14300 & $\mathrm{R}$ & $+/+$ & $-1+$ & - & Foster & $\mathrm{S}$ & $-1-$ & $-1-$ & - \\
\hline CIho 10644 & $\mathrm{R}$ & $-1-$ & $-1-$ & + & Heimdal & $\mathrm{S}$ & $-1+$ & $+/+$ & - \\
\hline CIho 9831 & $\mathrm{R}$ & $-/+$ & $-1-$ & - & Hiland & $\mathrm{S}$ & $-1-$ & $-1-$ & - \\
\hline Custer & $\mathrm{R}$ & $-1-$ & $+/+$ & - & Kindred & $\mathrm{S}$ & $+/-$ & $-1-$ & - \\
\hline Feebar & $\mathrm{R}$ & $+/-$ & $-1-$ & + & Manchuria & $\mathrm{S}$ & $+/-$ & $+/-$ & - \\
\hline Flynn1 & $\mathrm{R}$ & $+/-$ & $-1-$ & + & Nepal & $\mathrm{S}$ & $-1+$ & $-1+$ & - \\
\hline Glacier & $\mathrm{R}$ & $-1-$ & $-1-$ & - & Odessa & $\mathrm{S}$ & $-1+$ & $-1-$ & - \\
\hline Hor 2683-84 & $\mathrm{R}$ & $-1-$ & $+/+$ & - & Olli & $\mathrm{S}$ & $-1+$ & $-1+$ & - \\
\hline Hor 9471-87 & $\mathrm{R}$ & $-1+$ & $-1-$ & - & Rika & $\mathrm{S}$ & $-1+$ & $+/+$ & - \\
\hline Nomini & $\mathrm{R}$ & $-1+$ & $-1-$ & - & Robust & $\mathrm{S}$ & $-1-$ & $-1-$ & - \\
\hline ND16092 & $\mathrm{R}$ & $-1-$ & $+/+$ & - & Supi 1 & $\mathrm{~S}$ & $+/-$ & $+/+$ & - \\
\hline PC 11 & $\mathrm{R}$ & $-1+$ & $-1-$ & - & Trebi & $\mathrm{S}$ & $-1-$ & $+/-$ & - \\
\hline PC 84 & $\mathrm{R}$ & $+1-$ & $+/-$ & - & Velvon & $\mathrm{S}$ & $-1-$ & $-1+$ & - \\
\hline SP 1 & $\mathrm{R}$ & $-1+$ & $-1-$ & - & ZAU7 & $\mathrm{S}$ & $-1-$ & $-1+$ & - \\
\hline Starling & $\mathrm{R}$ & $-1+$ & $-1+$ & - & & & & & \\
\hline
\end{tabular}

${ }^{a}$ Resistance was evaluated in the greenhouse at Fargo, ND, in 2004.

${ }^{\mathrm{b}} \mathrm{R}$, resistant; $\mathrm{S}$, susceptible.

${ }^{\mathrm{c}}$ Existence (+) and absence (-) of alleles for SSLB resistance.

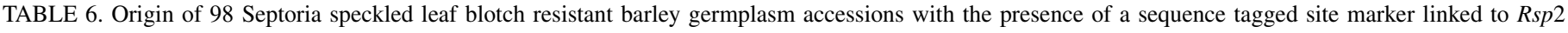
(SOPAH5, MWG938) or Rsp3 (SOPBA12) genes ${ }^{\mathrm{a}}$

\begin{tabular}{|c|c|c|c|c|}
\hline Identification & Origin & SOPAH5 & MWG938 & SOPBA12 \\
\hline CGN00476, CGN00477, CGN00478, CGN00480, CGN00481 & Turkey & & CGN00477, CGN00480, CGN00481 & \\
\hline CGN00482 & Iraq & & & \\
\hline CGN00826 & Argentina & & CGN00826 & \\
\hline $\begin{array}{l}\text { CGN01324, CGN01325, CGN01334, CGN01355, CGN01357, } \\
\text { CGN01358 }\end{array}$ & Nepal & & CGN01324, CGN01325, CGN01355 & \\
\hline $\begin{array}{l}\text { CGN01365, CGN01366, CGN01369, CGN01386, CGN01653, } \\
\text { CGN01654, CGN01676, CGN01679, CGN01700, CGN01701, } \\
\text { CGN01825, CGN01622 }\end{array}$ & Pakistan & CGN01386 & $\begin{array}{l}\text { CGN01369, CGN01386, CGN01653, } \\
\text { CGN01700 }\end{array}$ & CGN01366 \\
\hline CGN02455, CGN02465, CGN02476, CGN02520, CGN02527 & India & CGN02455 & CGN02455, CGN02520, CGN02527 & \\
\hline $\begin{array}{l}\text { CGN02554, CGN02555, CGN02556, CGN02563, CGN02568, } \\
\text { CGN02569, CGN02572, CGN02585, CGN02586, CGN02587, } \\
\text { CGN02591, CGN02592, CGN02593, CGN02595, CGN02596, } \\
\text { CGN02598, CGN02599, CGN02602, CGN02604, CGN02605, } \\
\text { CGN02609, CGN02613, CGN02620, CGN02624, CGN02625, } \\
\text { CGN02626, CGN02628, CGN02631, CGN02632, CGN02633, } \\
\text { CGN02634, CGN02637, CGN02638, CGN02639, CGN03372, } \\
\text { CGN11236, CGN11237, CGN11238, CGN11239, CGN11240, } \\
\text { CGN11242, CGN11243, CGN11245, CGN11246, CGN12916, } \\
\text { CGN12948, CGN12950, CGN12951, CGN12952, CGN12953, } \\
\text { CGN12954, CGN12955, CGN12956, CGN12957, CGN12958, } \\
\text { CGN12959, CGN12960, CGN12961, CGN12962, CGN12963 }\end{array}$ & Ethiopia & $\begin{array}{l}\text { CGN02554, } \\
\text { CGN02587, } \\
\text { CGN02602, } \\
\text { CGN02604, } \\
\text { CGN02626, } \\
\text { CGN02639 }\end{array}$ & $\begin{array}{l}\text { CGN02554, CGN02572, CGN02602, } \\
\text { CGN02639, CGN11240 }\end{array}$ & \\
\hline CGN02692 & Lebanon & & & \\
\hline CGN11856, CGN11857, CGN11861, CGN11864, CGN11865 & Syria & & & \\
\hline CGN12983 & Yemen & & & \\
\hline CGN13010 & China & & CGN13010 & \\
\hline CGN12986 & Russia & & CGN12986 & \\
\hline
\end{tabular}

a Seedling resistance was evaluated in the greenhouse at Fargo, ND, in 2005. 
testing. As the three described Rsp genes are phenotypically identical, these new STS markers may allow selection of resistant germplasm and the pyramiding of $R s p$ genes in a breeding program to produce barley lines with durable resistance.

\section{ACKNOWLEDGMENTS}

We thank R. Horsley, North Dakota State University, Fargo, for helping with the Osnabrock, ND, field experiment and for research discussions; J. Franckowiak for providing resistant parents CIho 14300, Clho 4780, and CIho 10644; and P. Gross and Y. Sun for help with greenhouse and field experiments.

\section{LITERATURE CITED}

1. Buchannon, K. W. 1961. Inheritance of reaction to Septoria passerinii Sacc., and Pyrenophora teres (Died.) Drechsl., and of row number, in barley. Ph.D. thesis, University of Saskatchewan, Saskatoon, Canada.

2. Cunfer, B. M. 2000. Stagonospora and Septoria diseases of barley, oat, and rye. Can. J. Plant Pathol. 22:332-348.

3. Federer, W. T. 1956. Augmented (or hoonuiaku) designs. Hawaiian Planters' Record LV(2):191-208.

4. Feuillet, C., and Keller, B. 1999. High gene density is conserved at sytenic loci of small and large grass genomes. Proc. Natl. Acad. Sci. USA 96:82658270.

5. Green, G. J., and Bendelow, V. M. 1961. Effect of speckled leaf blotch, Septoria passerinii Sacc., on the yield and malting quality of barley. Can. J. Plant Sci. 41:431-435.

6. Green, G. J., and Dickson, J. G. 1957. Pathological histology and varietal reactions in Septoria leaf blotch of barley. Phytopathology 47:73-79.

7. Haley, S. D., Afanador, L., and Kelly, J. D. 1994. Selection for monogenic pest resistance traits with coupling- and repulsion-phase RAPD markers. Crop. Sci. 34:1061-1066.

8. Hammond-Kosak, K. E., and Jones, J. D. G. 1997. Plant disease resistance genes. Annu. Rev. Plant Physiol. Plant Mol. Biol. 48:575-607.

9. Hernandez, P., Rubio, M. J., and Martin, A. 1996. Development of RAPD markers in tritordeum and addition lines of Hordeum chilense in Triticum aestivum. Plant Breed. 115:52-56.

10. Karp, A., Seberg, O., and Buiatti, M. 1996. Molecular techniques in the assessment of botanical diversity. Ann. Bot.-London 78:143-149.

11. Keim, P., Shoemaker, R. C., and Palmer, R. G. 1989. Restriction fragment length polymorphism diversity in soybean. Theor. Appl. Genet. 77:786792.

12. Kelly, J. D., and Miklas, P. N. 1998. The role of RAPD markers in breeding for disease resistance in common bean. Mol. Breed. 4:1-11.

13. Kosambi, D. D. 1944. The estimation of map distances from recombination values. Ann. Eugen. 12:172-175.

14. Lee, S. H., and Neate, S. M. 2007. Molecular mapping of $R s p 1$, Rsp 2 , and Rsp 3 genes conferring resistance to Septoria speckled leaf blotch in barley. Phytopathology 97:155-161.

15. Metcalfe, D. R., Buchannon, K. W., MacDonald, W. C., and Reinbergs, E. 1970. Relationships between the 'Jet' and 'Milton' genes for resistance to loose smut and genes for resistance to other barley diseases. Can. J. Plant Sci. 50:423-427.

16. Paran, I., and Michelmore, R. W. 1993. Development of reliable PCRbased markers linked to downy mildew resistance genes in lettuce. Theor. Appl. Genet. 85:985-993.

17. Peterson, R. F. 1956. Progress report, 1949-54. Cereal Breeding Laboratory, Winnipeg, Manitoba, Canada.

18. Rasmusson, D. C., and Rogers, W. E. 1963. Inheritance of resistance to Septoria in barley. Crop Sci. 3:161-162.

19. Singh, S., Sidhu, J. S., Huang, N., Vikal, Y., Li, Z., Brar, D. S., Dhaliwal, H. S., and Khush, G. S. 2001. Pyramiding three bacterial blight resistance genes $(x a 5, x a 13$, and $\mathrm{Xa21})$ using marker-assisted selection into indica rice cultivar PR106. Theor. Appl. Genet. 102:1011-1015.

20. Toubia-Rahme, H., and Steffenson, B. J. 1999. Sources of resistance to Septoria passerinii in Hordeum vulgare and $H$. vulgare ssp. spontaneum. Pages 156-158 in: Septoria/Stagonospora diseases of cereals: A compilation of global research. Pages 156-158 in: Proc. 5th Int. Workshop. M. van Ginkel, A. McNab, and J. Krupinsky, eds. CIMMYT, Mexico, D.F.

21. Toubia-Rahme, H., and Steffenson, B. J. 2004. Sources of resistance to septoria speckled leaf blotch caused by Septoria passerinii in barley. Can. J. Plant Pathol. 26:358-364.

22. Weber, W. E., and Wricke, G. 1994. Genetic markers in plant breeding. Advances in Plant Breeding No. 16. Parey Scientific, Berlin.

23. Williams, J. G. K., Kubelik, A. R., and Livak, K. J. 1990. DNA polymorphisms amplified by arbitrary primers are useful as genetic markers. Nucleic Acids Res. 18:6531-6535.

\section{Erratum}

A correction was made to page 162 of this article on 23 February 2007. On page 162 , the acronym "MAS" in the penultimate line of the abstract was written incorrectly. 